\title{
molecules
}

ISSN 1420-3049

http://www.mdpi.org

Full Paper

\section{Synthesis and Biological Evaluation of Rigid Polycyclic Derivatives of the Diels-Alder Adduct Tricyclo[6.2.1.0 $\left.0^{2,7}\right]$ undeca-4,9-dien-3,6-dione}

Felicia Megumi Ito ${ }^{1}$, Jacqueline Marques Petroni ${ }^{1}$, Dênis Pires de Lima ${ }^{1}$, Adilson Beatriz ${ }^{1, *}$, Maria Rita Marques ${ }^{2}$, Manoel Odorico de Moraes ${ }^{3}$, Letícia Veras Costa-Lotufo ${ }^{3}$, Raquel Carvalho Montenegro ${ }^{3}$, Hemerson Iury Ferreira Magalhães ${ }^{3}$ and Cláudia do Ó Pessoa ${ }^{3}$

${ }^{1}$ Department of Chemistry, Federal University of Mato Grosso do Sul, Campo Grande, MS, Brazil. Emails:megumi@nin.ufms.br, jacque_petroni@hotmail.com,dlima@nin.ufms.br

${ }^{2}$ Department of Morphophysiology, Federal University of Mato Grosso do Sul, Campo Grande, MS, Brazil. E-mail: mrmarx@nin.ufms.br

${ }^{3}$ Department of Physiology and Pharmacology, Federal University of Ceará, Fortaleza, CE, Brazil. E-mail: odorico@ufc.br, lvcosta@secrel.com.br, hemersoniury@yahoo.com.br, cpessoa@ufc.br

* Author to whom correspondence should be addressed; E-mail: adilbeat@nin.ufms.br; Homepage: http://www.dqi.ufms.br/ lp4/adilson.htm.

Received: 30 January 2007; in revised form: 14 February 2007 / Accepted: 16 February 2007 / Published: 27 February 2007

\begin{abstract}
Part of our research program concentrates on the discovery of new bioactive compounds prepared either by total synthesis or molecular transformation of compounds with bioactivity profiles. In this work we have focused our interest on chemical transformations of the Diels-Alder adduct tricyclo[6.2.1.0 $\left.0^{2,7}\right]$ undeca-4,9-dien-3,6-dione in order to obtain cage-like compounds and derivatives, followed by an evaluation of their biological activity.
\end{abstract}

Keywords: Tricyclo[6.2.1.0 2,7 undecane ring system, cage-like compounds, Diels-Alder adducts, biological activity. 


\section{Introduction}

Since the discovery of the Diels-Alder reaction [1], it has become one of the most employed strategies in organic synthesis [2]. This all began in 1928, when the cycloaddition between cyclopentadiene (1) and p-benzoquinone (2), forming mostly the endo adduct tricyclo[6.2.1.0 $\left.0^{2,7}\right]$ undeca-4,9-dien-3,6-dione (3), as shown in Scheme 1, was described.

Scheme 1. Preparation of tricyclo [6.2.1.0 $\left.0^{2,7}\right]$ undeca-4,9-dien-3,6-dione.

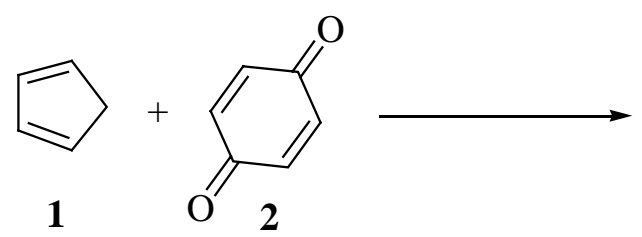<smiles>O=C1C=CC(=O)[C@@]2(C3CC3)NC1C1C=CC2CC1</smiles>

A unique aspect of adduct $\mathbf{3}$ is its high symmetry, which allows for facile selective reactions at one or both carbonyl groups by means of classical and non-classical reagents, including microbial transformations [3]. Another feature to be considered is its cage-like framework, which forces functional groups into close spatial proximity, facilitating subsequent reactions, as exemplified, for instance, by the synthesis of Cookson's diketone (4) [4] (Scheme 2).

Scheme 2. Preparation of Cookson's diketone (4).

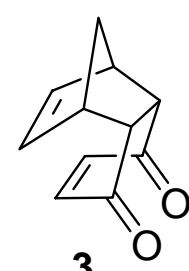

3

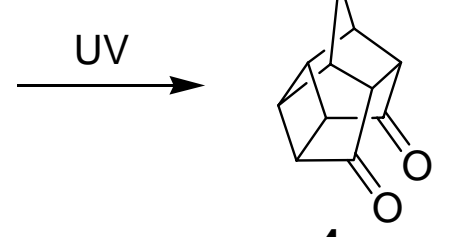

4

Although compound $\mathbf{3}$ has been extensively studied, its use in the medicinal chemistry field has not been exploited very much. On the other hand, there is considerable interest nowadays in studying the biological activity of cage-like rigid polycyclic molecules, which owing to their structural peculiarities, may interact in a specific way with biological receptors and/or trap smaller chemical species in their interior. It is known, for example, that the incorporation of a rigid carbogenic structure in biologically active compounds often increases their physiological activity. One of their advantages is a slowing down of metabolic degradation and consequent prolongation of the activity [5-7]. 
Figure 1: Examples of bioactive cage-like polycyclic compounds.

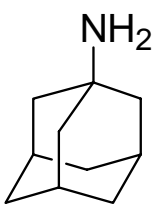

5

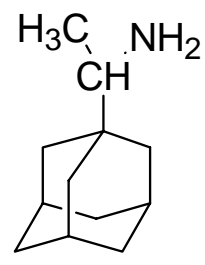

6

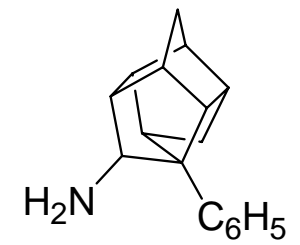

7<smiles>CC1(C)C2CCC1(C)C(N)C2</smiles>

8

Considering the important antiviral activity of amantadine (5) and rimantadine (6), additional studies related to cage-like polycyclic compounds led to the discovery of other compounds with similar properties, such as the pentacycloundecanes 7 and 8 [6] (Figure 1).

Accordingly, as a part of a research program aimed at finding new synthetic compounds with interesting bioactivity profiles, we decided to investigate the preparation of some rigid polycyclic oxygenated compounds, taking advantage of the structural versatility of the Diels-Alder adduct $\mathbf{3}$. The central idea in this work was to make accessible new structurally complex molecules which are both easy to prepare and endowed with potential biological activity.

\section{Results and Discussion}

\section{Chemistry}

The reaction shown in Scheme 1 is widely known in literature [2, 8-11], however, from an experimental point of view, a few drawbacks can be noted, such as the use of toxic solvents and the need to perform the reaction at very low temperatures. These features prompted us to search for a more efficient and higher yielding methodology to generate 3 . As a result of these studies the cycloaddition reaction was performed in a 5:1 mixture of hexane-ethyl acetate to both force the kinetic control of the reaction and to solubilize the reagents. This procedure led to a $97 \%$ yield of the endo isomer after recrystallization from hexane, as proven by its ${ }^{1} \mathrm{H}$-NMR spectrum.

Schemes 3 and 4 show some of the compounds chosen for chemical transformation and screening for biological activity that were prepared from adduct 3. Compounds $\mathbf{9}$ and $\mathbf{1 0}$ (Scheme 3) were easily obtained using described methods [3, 12]. As one may observe, the keto-alcohol 10 possesses appropriate structural and chemical functionality for the insertion of new groups and building rigid cage-like polycyclic molecules, in conformity with our initial plan.

Scheme 3. Selective reductions of tricyclo[6.2.1.0 $\left.0^{2,7}\right]$ undeca-4,9-dien-3,6-dione (3).

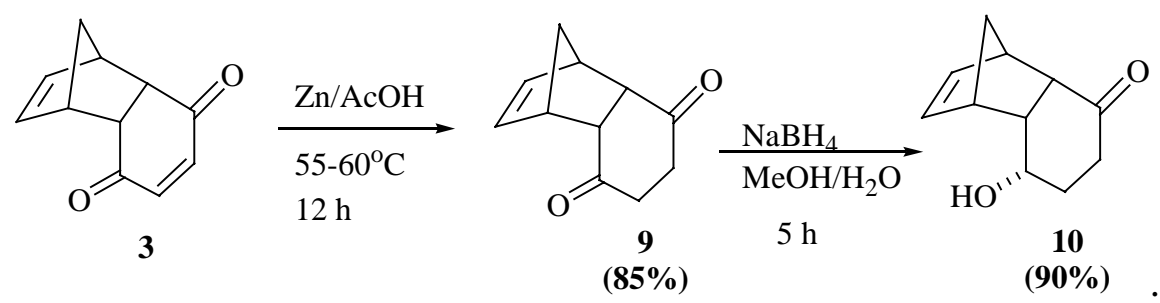


The structures of compounds $\mathbf{3 , \mathbf { 9 }}$ and $\mathbf{1 0}$ were confirmed by comparison of their spectroscopic data with those reported in the literature [8, 12 and 3, respectively]. Next, and starting from compound 10, five rigid polycyclic compounds were obtained, possessing various and diverse chemical functionalities, as shown in Scheme 4.

Scheme 4. Syntheses of derivatives of keto-alcohol 10.
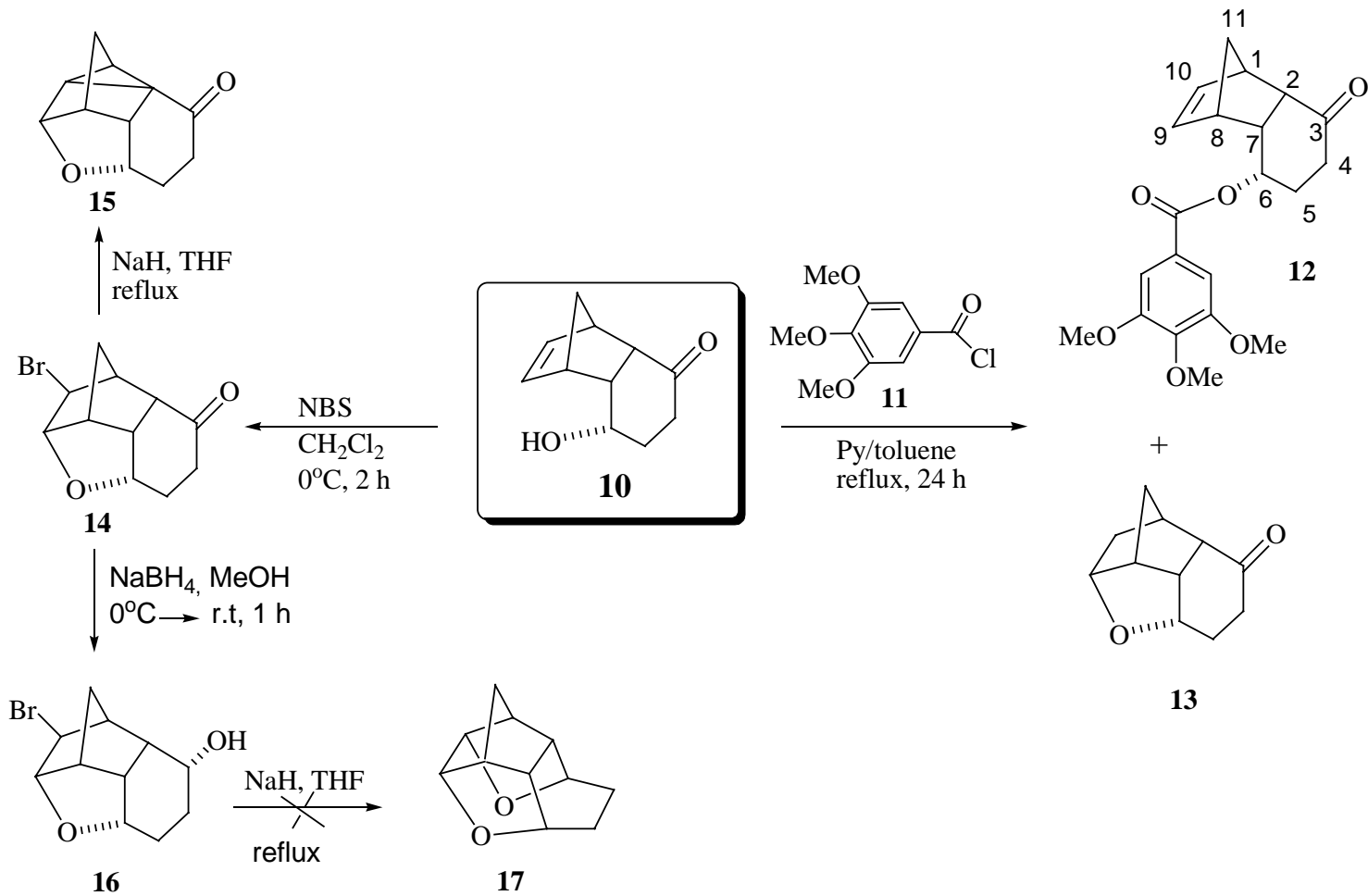

13

Gallate 12 was prepared by submitting 10 to simple esterification in refluxing toluene with the acid chloride $\mathbf{1 1}$ in the presence of pyridine. The structure and stereochemistry of the resulting ester $\mathbf{1 2}$ were assigned based on NMR spectral analyses, including HSQC, HMBC, COSY and NOESY experiments. The ${ }^{1} \mathrm{H}-\mathrm{NMR}$ spectrum showed a multiplet at $5.52 \mathrm{ppm}$, assigned to the hydrogen attached to C6, which is probably deshielded by the ester carbonyl. It also showed a multiplet $(4 \mathrm{H})$ at 1.95-2.45 ppm, assigned to the two methylene groups at C4 and C5. The two doublets at 1.26 and 1.37 $\operatorname{ppm}(J=8.4 \mathrm{~Hz})$ correspond to the geminal methylene protons at C11. The broad signal at $3.24 \mathrm{ppm}$ was ascribed to the hydrogen attached to $\mathrm{C} 1$ and the signals of the protons on $\mathrm{C} 2, \mathrm{C} 7$ and $\mathrm{C} 8$ were superimposed at around 2.91-3.03 ppm. The olefinic hydrogens of C9 and C10 appear as doubledoublets at 5.93 and $6.2 \mathrm{ppm}$, respectively, while the aromatic ring singlets and methoxyls are observed at 7.21 and $3.83 \mathrm{ppm}$. A comparison of the NMR data of substance $\mathbf{1 2}$ with that of a similar tricyclic ketoester described by Marchand et al., which contains an endo-6-OC(O)Ar group were $\mathrm{Ar}=$ 3,5-dinitrophenyl [3], also confirmed the structure proposed for compound 12. Compound 13 was obtained along with 12 (Scheme 4), probably due to the mild acid conditions of reaction mixture favoring protonation of double bond followed by ring closure via the hydroxyl group [13] (Scheme 5). With the purpose of verifying this proposal, we checked the stability of compound $\mathbf{1 0}$. We have observed that $\mathbf{1 0}$ is stable in pure ethyl acetate, however, it is rapidly converted into $\mathbf{1 3}$ when a small amount of $p$-toluenesulfonic acid is added to the solution. 
Scheme 5. Mechanistic proposal for the formation of compound 13.

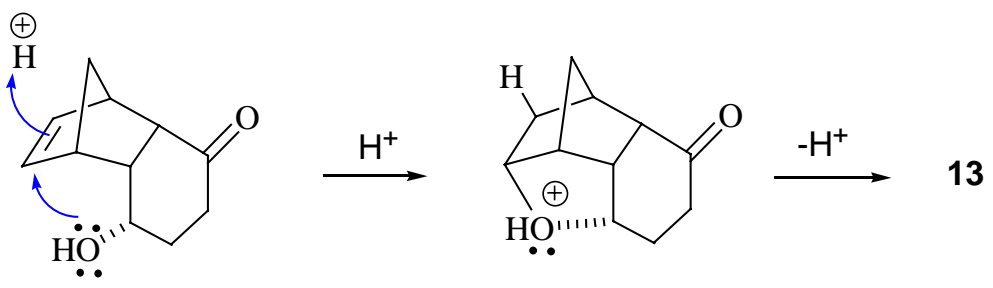

The structure of compound $\mathbf{1 3}$ was confirmed on the basis of its spectral data. In contrast to 10, no olefinic proton signals were observed in the ${ }^{1} \mathrm{H}-\mathrm{NMR}$ spectrum. As main signals a multiplet at 4.22 ppm, ascribed to the hydrogen attached to C9, and the triplet at $4.41 \mathrm{ppm}$ assigned to the hydrogen at C6 were observed. The ${ }^{13} \mathrm{C}-\mathrm{NMR}$ data were in agreement with the proposal structure. The appearance of $\mathrm{C} 10$ as an additional secondary carbon $\left(\mathrm{CH}_{2}\right)$ at $35.1 \mathrm{ppm}$ was decisive for confirmation of the $\mathbf{1 0}$ $\rightarrow \mathbf{1 3}$ transformation. Moreover, the mass spectrum registered the expected molecular ion $\left(\mathrm{M}^{+}\right)$at $\mathrm{m} / \mathrm{z}$ $=178$.

The bromoether 14 was obtained in quantitative yield from alcohol $\mathbf{1 0}$ by bromination with NBS in dichloromethane [14]. Treatment of tetracycle $\mathbf{1 4}$ with $\mathrm{NaH}$ in THF under reflux induced abstraction of the acidic proton at $\mathrm{C} 2$ and subsequent intramolecular cyclopropanation leading to formation of compound 15. Its structure was confirmed by spectroscopic studies comprising 2D experiments (COSY, HSQC, HMBC and NOESY). The ${ }^{1} \mathrm{H}-\mathrm{NMR}$ spectrum showed the hydrogen at C6 as a multiplet at $4.35 \mathrm{ppm}$, whereas the C9 hydrogen was a double doublet at $4.55 \mathrm{ppm}$. The hydrogen of the cyclopropane ring $(\mathrm{C} 10-\mathrm{H})$ is in a current shielding region and can be seen at $1.69 \mathrm{ppm}$, coupled with the $\mathrm{C} 9-\mathrm{H}(J=5.0 \mathrm{~Hz})$. The triplet at $2.51 \mathrm{ppm}$ was attributed to the $\mathrm{C} 8-\mathrm{H}$ that is coupled with the C9-H and C7-H $(J=2.8 \mathrm{~Hz})$. The ${ }^{13} \mathrm{C}-\mathrm{NMR}$ spectrum showed signals in accordance with the chemical transformation performed, mainly at 21.8 (C1), 33.1 (C2) and 35.3 (C10) ppm (see Table 1). The mass spectrum showed the molecular ion peak $\left(\mathrm{M}^{+}\right)$at $\mathrm{m} / \mathrm{z}=176$.

When we attempted to prepare the highly strained compound $\mathbf{1 7}$ by reduction of the carbonyl in $\mathbf{1 4}$ from the convex face, followed by displacement of the bromide, only the known bromohydrin 16 [15] was formed (Scheme 4). Even forcing conditions, such as treatment of $\mathbf{1 6}$ with $\mathrm{NaH}$ in THF under reflux, failed to yield $\mathbf{1 7 .}$

Bromohydrin 16 (m.p. 136-138 ${ }^{\circ} \mathrm{C}$; Lit. [15], m.p. 133-134 ${ }^{\circ} \mathrm{C}$ ), was characterized by means of its spectroscopic data $\left({ }^{1} \mathrm{H}\right.$ - and ${ }^{13} \mathrm{C}-\mathrm{NMR}$, IR) and mass spectrum (cf. Experimental Part). Its mass spectrum showed molecular ion peak at $\mathrm{m} / \mathrm{z} 258 / 260$ and a (M -18) ${ }^{+}$peak at $\mathrm{m} / \mathrm{z} 240 / 242$, due to loss of one water molecule from the hexane ring system.

Table 1 list the experimental ${ }^{13} \mathrm{C}$-NMR data of compounds 13, 14, 15 and 16, allowing a rapid comparison of the chemical shifts of all carbons of these molecules and supporting the main transformations carried out on the 6,9-epoxytricyclo[6.2.1.0 $\left.0^{2,7}\right]$ undecane ring system (Figure 2).

\section{Figure 2.}

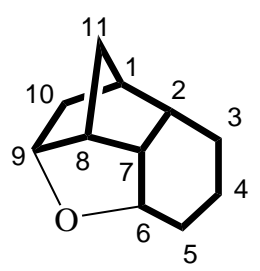


Table $1 .{ }^{13} \mathrm{C}-\mathrm{NMR}\left(\mathrm{CDCl}_{3}\right)$ spectral data of the compounds $13,14,15$ and 16 a

\begin{tabular}{|c|c|c|c|c|}
\hline \multirow[t]{2}{*}{ Position $^{\mathrm{b}}$} & 13 & 14 & 16 & 15 \\
\hline & $\mathrm{C}_{\delta}$ & $\mathrm{C}_{\delta}$ & $\mathrm{C}_{\delta}$ & $\mathrm{C}_{\delta}$ \\
\hline 1 & 39.3 & 42.2 & 42.9 & 21.8 \\
\hline 2 & 51.2 & 49.8 & 39.5 & 33.1 \\
\hline 3 & 214.0 & 211.8 & 69.7 & 209.4 \\
\hline 4 & 37.4 & 35.0 & 26.7 & 38.3 \\
\hline 5 & 26.5 & 25.9 & 26.1 & 30.4 \\
\hline 6 & 74.4 & 75.3 & 76.1 & 74.1 \\
\hline 7 & 43.5 & 46.9 & 44.2 & 42.0 \\
\hline 8 & 49.1 & 48.6 & 49.1 & 46.3 \\
\hline 9 & 79.7 & 88.4 & 88.7 & 82.2 \\
\hline 10 & 35.1 & 55.1 & 56.5 & 35.3 \\
\hline 11 & 37.2 & 34.9 & 35.4 & 30.3 \\
\hline
\end{tabular}

\section{Biological Evaluation}

\section{Assay for cytotoxic activity}

Cytotoxic analyses by the MTT method are used in the screening program of the U.S. National Cancer Institute (NCI), which tests more than 10,000 samples per year [16]. It is a fast, sensitive and cheap methodology, described for the first time by Mosman [17] in 1983 and subsequently modified in 1996 by Alley et al. [18]. This evaluation allows one to easily determine the cytotoxicity of a particular compound, but it does not provide any insight into the mechanism of action [19].

The cytotoxic activity of compounds $3,9,10,12,14,15,16$ and 18 are listed in Table 2, with the respective $\mathrm{IC}_{50}$ values. Among the eight samples analyzed, compound $\mathbf{3}$ showed moderate albeit unspecific cytotoxicity, with IC $_{50}$ values of $11.34,13.62$ and $13.52 \mu \mathrm{g} / \mathrm{mL}$ towards the HL-60, HCT-8 and MDA-MB 435 cell lines, respectively. Similarly, the novel gallate $\mathbf{1 2}$ was cytotoxic towards the HCT-8, SF-295 and MDA-MB 435 cell lines, with IC $_{50}$ values of 6.68, 7.58 and $13.51 \mu \mathrm{g} / \mathrm{mL}$, respectively.

Figure 3: Methyl gallate.<smiles>COC(=O)c1cc(OC)c(OC)c(OC)c1</smiles> 
On the other hand, methyl gallate 18 (Figure 3) did not show any cytotoxic effects on the cell growth of the tested cell lines, suggesting that the cage structure present in $\mathbf{1 2}$ may play an important role in any observed increase of activity. Compound 9 was noticeably cytotoxic towards the MDA-MB 435 cell line with an $\mathrm{IC}_{50}$ of $10.4 \mu \mathrm{g} / \mathrm{mL}$. On the other hand, the other samples did not show important cytotoxic effects.

Table 2. Cytotoxicity of compounds $3,9,10,12,14,15,16$ and 18, based on inhibition of tumor cell growth.

\begin{tabular}{|c|c|c|c|c|}
\hline \multirow[t]{2}{*}{ Compound } & \multicolumn{4}{|c|}{$\begin{array}{c}\text { Cells }^{\mathrm{a}} \\
\text { IC }_{50}{ }^{\mathrm{b}}[\mu \mathrm{g} / \mathrm{mL}, \text { confidence interval }]\end{array}$} \\
\hline & HL-60 & НСТ-8 & SF-295 & MDA-MB 435 \\
\hline 3 & $\begin{array}{c}11.34 \\
(8.68-14,80)\end{array}$ & $\begin{array}{c}13.62 \\
(5.52-33.63)\end{array}$ & $>25$ & $\begin{array}{c}13.52 \\
(11.57-15.80)\end{array}$ \\
\hline 9 & $>25$ & $>25$ & $>25$ & $\begin{array}{c}10.47 \\
(4.80-22.05)\end{array}$ \\
\hline 10 & $>25$ & $>25$ & $>25$ & $>25$ \\
\hline 12 & $>25$ & $\begin{array}{c}6.68 \\
(4.22-10.56)\end{array}$ & $\begin{array}{c}7.58 \\
(6.12-9.39)\end{array}$ & $\begin{array}{c}13.51 \\
(11.16-16.37)\end{array}$ \\
\hline 14 & $>25$ & $>25$ & $>25$ & $>25$ \\
\hline 15 & $>25$ & $>25$ & $>25$ & $>25$ \\
\hline 16 & $>25$ & $>25$ & $>25$ & $>25$ \\
\hline 18 & $>25$ & $>25$ & $>25$ & $>25$ \\
\hline
\end{tabular}

${ }^{\text {a }}$ Cells were plated in 96 -well plates incubated with a $5 \% \mathrm{CO}_{2}$ atmosphere, at $37^{\circ} \mathrm{C}$, for $72 \mathrm{~h}$, in presence of concentrations of pure compounds $(0.39-25 \mu \mathrm{g} / \mathrm{mL})$. Each concentration was tested in triplicate and the analyses were performed in duplicate.

b The IC 50 corresponds to inhibitory concentration for 50\% of cellular growth (95\% Confidence Interval).

\section{Assay of hemolytic activity in Swiss mouse (Mus musculus) erythrocytes}

In order to verify whether the observed cytotoxic and antimitotic activities are related to membrane disruption, compounds were tested for their ability to induce lysis of mouse erythrocytes. The erythrocyte membrane is a dynamic structure that can dictate significant changes in its interaction with drugs $[20,21]$. The results revealed the absence of hemolytic activity for compounds 3, 12, 9, 16 and 18 at the highest tested concentration $(200 \mu \mathrm{g} / \mathrm{mL})$, suggesting that both cytotoxic and antimitotic activities were not related to the lytic properties or membrane instability induced by these compounds, which may be probably caused by a more specific pathway. The others compounds were not tested. 


\section{Conclusions}

From the results presented it may be concluded that a polycyclic framework could be a useful scaffold for generating new lead compounds with biological activity and further synthetic studies are warranted, aimed at the preparation of hybrid compounds similar, for instance, to compound 12, which represents a kind of hybrid between a polycyclic and a trimethoxy residue found in some cytotoxic molecules such as podophyllotoxin and colchicine. Another topic of potential interest would be molecular modeling studies aimed at revealing possible structural modifications that could be made in the prepared compounds so they would be active in the receptor site(s) of proteins involved in the structure-cytotoxicity activity relationships, such as tubuline.

\section{Experimental Section}

\section{General}

${ }^{1} \mathrm{H}$ - and ${ }^{13} \mathrm{C}$-NMR spectra were obtained at 300 and $75 \mathrm{MHz}$ respectively on a Bruker AVANCE DPX-300 spectrometer. Chemical shifts were referenced to TMS and coupling constants are given in Hertz. Infrared (IR) spectra were obtained on a Perkin Elmer equipment model 783. Mass spectra were recorded on a GC/Mass Spectrometer model QP5000 (Shimadzu). Solvents were purified before use and chemical reagents were commercially available and used without previous treatment. p-Benzoquinone was prepared by oxidation of hydroquinone [22]. Column chromatography was performed using Merck $60 \AA$ (70-230 mesh) silica gel, eluting with a hexane-ethyl acetate gradient. TLC analyses employed Merck (60F254/0.2 mm) sílica gel plates Melting points were recorded on Köffler equipment and are reported without correction.

\section{Chemistry}

Synthesis of rel-(1S,2S,7R,8R)-tricyclo[6.2.1.0 $\left.0^{2,7}\right]$ undeca-4,9-dien-3,6-dione (3)

Cyclopentadiene (14.6 g, $221 \mathrm{mmol}$ ) was added to a solution of p-benzoquinone (22 g, $203 \mathrm{mmol}$ ) in hexane-ethyl acetate $(5: 1)$, cooled at $0^{\circ} \mathrm{C}$. The resulting mixture was stirred for 4 hours. Afterwards, the solvent was removed under vacuum and the product was recrystallized from hexane to give the title compound as yellow crystals: $97 \%$ yield; m.p.: $71-75^{\circ} \mathrm{C} ;{ }^{1} \mathrm{H}-\mathrm{NMR}\left(\mathrm{CDCl}_{3}\right) \delta(\mathrm{ppm}): 1.46(\mathrm{dt}, \quad J=$ 8.8/1.3 Hz, 1H), 1.55 (dt, $J=8.8 / 1.8 \mathrm{~Hz}, 1 \mathrm{H}), 3.20$ (m, 2H), 3.50 (m, 2H), 6.09 (t, $J=1.8 \mathrm{~Hz}, 2 \mathrm{H}$ ), $6.60(\mathrm{~s}, 2 \mathrm{H}) ;{ }^{13} \mathrm{C}-\mathrm{NMR}\left(\mathrm{CDCl}_{3}\right) \delta(\mathrm{ppm}): 43.4(\mathrm{CH}), 46.3(\mathrm{CH}), 49.8\left(\mathrm{CH}_{2}\right), 67.7(\mathrm{CH}), 131.3(\mathrm{CH})$, $136.6(\mathrm{CH})$.

Synthesis of rel-(2S,3S,4S,5S,6S,10S,1R,9R)-2-bromine-3,6-epoxytricyclo[6.2.1.0 $0^{5,10}$ ]undecan-9-ol (16)

$\mathrm{NaBH}_{4}(0.034 \mathrm{~g}, 0.89 \mathrm{mmol})$ was added to an ice-bath-cooled solution of compound 14 [14] (0.153 g, $0.6 \mathrm{mmol})$ in $\mathrm{MeOH}(1.6 \mathrm{~mL})$. The ice bath was then removed and the reaction mixture was stirred for 1 hour at room temperature, before being quenched by addition of a drop of acetic acid. The mixture was extracted with $\mathrm{CH}_{2} \mathrm{Cl}_{2}(3 \times 2 \mathrm{~mL})$ and washed with distilled water. The organic layer was 
dried over anhydrous $\mathrm{MgSO}_{4}$, filtered and the solvent was removed under vacuum. The product was purified by flash chromatography on silica gel column using hexane-ethyl acetate $(2: 1)$ as eluent to afford a white amorphous solid: $72 \%$ yield; m.p.: $136-138^{\circ} \mathrm{C} ;{ }^{1} \mathrm{H}-\mathrm{NMR}\left(\mathrm{CDCl}_{3}\right) \delta$ (ppm): 1.36-1.42 (m, 1H), 1.50 (d, $J=11 \mathrm{~Hz}, 1 \mathrm{H}), 1.59-1.67$ (m, 3H), 1.97 (ddd, $J=17.8 / 6.5 / 3.2 \mathrm{~Hz}, 1 \mathrm{H}), 2.13$ (d, $J=$ $11 \mathrm{~Hz}, 1 \mathrm{H}), 2.30$ (m, 1H), 2.36 (m, 1H), 2.61 (broad signal, -OH), 2.90 (m, 1H), 3.95 (dd, $J=17.8 / 7.8$ $\mathrm{Hz}, 1 \mathrm{H}), 4.15$ (m, 1H), 4.22 (d, $J=2.0 \mathrm{~Hz}, 1 \mathrm{H}), 4.54$ (d, $J=5 \mathrm{~Hz}, 1 \mathrm{H}) ;{ }^{13} \mathrm{C}-\mathrm{NMR}\left(\mathrm{CDCl}_{3}\right) \delta(\mathrm{ppm})$ : $26.1\left(\mathrm{CH}_{2}\right), 26.7\left(\mathrm{CH}_{2}\right), 35.4\left(\mathrm{CH}_{2}\right), 39.5(\mathrm{CH}), 42.9(\mathrm{CH}), 44.2(\mathrm{CH}), 49.1(\mathrm{CH}), 56.5(\mathrm{CH}), 69.7$ (CH), $76.1(\mathrm{CH}), 88.7(\mathrm{CH})$; IR $(\mathrm{KBr})$ y $\left(\mathrm{cm}^{-1}\right)$ : 3269, 2975-2869; MS m/z: $260\left[(\mathrm{M}+2)^{+},{ }^{81} \mathrm{Br}\right], 258$ $\left(\mathrm{M}^{+},{ }^{79} \mathrm{Br}\right), 242\left[\left(\mathrm{M}-\mathrm{H}_{2} \mathrm{O}+2\right)+{ }^{+81} \mathrm{Br}\right], 240\left[\left(\mathrm{M}-\mathrm{H}_{2} \mathrm{O}\right){ }^{+},{ }^{79} \mathrm{Br}\right]$.

Synthesis of rel-(1S,3S,7S,2R,8R)-6-oxo-3-(3,4,5-trimethoxyphenylcarbonyloxy) tricyclo[6.2.1.0 $0^{2,7}$ undec-9-ene (12) and rel- (1S,2S,6S,8S,7R,9R)-6,9-epoxytricyclo[6.2.1.0 2,7]undecan-3-one (13)

Under a nitrogen atmosphere, thionyl chloride $(0.270 \mathrm{~mL} ; 3.6 \mathrm{mmol})$ was added to a solution of 3,4,5-trimethoxybenzoic acid (0.385 g; $1.8 \mathrm{mmol})$ in $\mathrm{CH}_{2} \mathrm{Cl}_{2}(5.5 \mathrm{~mL})$. The mixture was refluxed for 4 hours. After evaporation of the solvent under reduced pressure the acid chloride $\mathbf{1 1}$ was dissolved in anhydrous toluene $(5.5 \mathrm{~mL})$. To this solution it was added compound $\mathbf{1 0}$ (0.318 g, $1.8 \mathrm{mmol})$ and pyridine $(5.0 \mathrm{~mL})$ and the mixture was refluxed during 24 hours. The reaction was monitored by TLC and after completion it was diluted with dichloromethane and the resulting solution was washed with a saturated solution of $\mathrm{CuSO}_{4}$. The organic layer was dried over anhydrous $\mathrm{Na}_{2} \mathrm{SO}_{4}$ and concentrated under reduced pressure. The products were purified by silica gel column chromatography using hexane-ethyl acetate (1:1) as eluent. Compound 12: white solid: $15 \%$ yield; m.p.: $42-46{ }^{\circ} \mathrm{C} ;{ }^{1} \mathrm{H}-\mathrm{NMR}$ $\left(\mathrm{CDCl}_{3}\right) \delta(\mathrm{ppm}): 1.26$ (d, $\left.J=8.4 \mathrm{~Hz}, 1 \mathrm{H}\right), 1.37$ (d, $\left.J=8.4 \mathrm{~Hz}, 1 \mathrm{H}\right), 1.92-2.05(\mathrm{~m}, 2 \mathrm{H}), 2.16-2.29(\mathrm{~m}$, 2H), 2.91-3.03 (m, 3H), 3.24 (broad signal, 1H), 3.83 (s, 9H), 5.52 (m, 1H), 5.93 (dd, $J=5.3 / 2.7 \mathrm{~Hz}$, $1 \mathrm{H}), 6.12$ (dd, $J=5.3 / 2.9 \mathrm{~Hz}, 1 \mathrm{H}), 7,21(\mathrm{~s}, 2 \mathrm{H}) ;{ }^{13} \mathrm{C}-\mathrm{NMR}\left(\mathrm{CDCl}_{3}\right) \delta(\mathrm{ppm}): 25.6\left(\mathrm{CH}_{2}\right), 35.6\left(\mathrm{CH}_{2}\right)$, $44.4(\mathrm{CH}), 45.0(\mathrm{CH}), 45.4(\mathrm{CH}), 49.6\left(\mathrm{CH}_{2}\right), 51.7(\mathrm{CH}), 56.1\left(\mathrm{CH}_{3}\right), 60.8\left(\mathrm{CH}_{3}\right), 70.0(\mathrm{CH}), 106.8$ (CH), $125.0(\mathrm{C}), 135.4(\mathrm{CH}), 135.8(\mathrm{CH}), 142.2(\mathrm{C}), 152.9(\mathrm{C}), 165.1(\mathrm{C}), 211.5(\mathrm{C}=\mathrm{O})$. Compound 13: colorless oil: $9 \%$ yield; ${ }^{1} \mathrm{H}-\mathrm{NMR}\left(\mathrm{CDCl}_{3}\right) \delta(\mathrm{ppm}): 1.31$ (d, $\left.J=10.4,1 \mathrm{H}\right), 1.35$ (d, $J=3.2 \mathrm{~Hz}$, 1H), 1.44 (m, 1H), 1.50 (m, 1H), 1.82 (tdd, $J=13.0 / 13.0 / 5.4 / 1.3 \mathrm{~Hz}, 1 \mathrm{H}), 2.12$ (m, 1H), 2.19 (m, 1H), $2.26(\mathrm{~d}, J=5.4 \mathrm{~Hz}, 1 \mathrm{H}), 2.37-2.58(\mathrm{~m}, 3 \mathrm{H}), 2.89(\mathrm{t}, J=4.0 \mathrm{~Hz}, 1 \mathrm{H}), 4.22(\mathrm{~m}, 1 \mathrm{H}), 4.40(\mathrm{t}, J=6.3 \mathrm{~Hz}$, $1 \mathrm{H}) ;{ }^{13} \mathrm{C}-\mathrm{NMR}\left(\mathrm{CDCl}_{3}\right) \delta(\mathrm{ppm}): 26.5\left(\mathrm{CH}_{2}\right), 35.1\left(\mathrm{CH}_{2}\right), 37.2\left(\mathrm{CH}_{2}\right), 37.4\left(\mathrm{CH}_{2}\right), 39.3(\mathrm{CH}), 43.5$ $(\mathrm{CH}), 49.1(\mathrm{CH}), 51.2(\mathrm{CH}), 74.4(\mathrm{CH}), 79.7(\mathrm{CH}), 214.0(\mathrm{C}=\mathrm{O}) ; \mathrm{MS}$ m/z: $178\left[\mathrm{M}^{+}\right]$.

Synthesis of 6,9-epoxytetracyclo[6.2.1.0 $\left.0^{2,7} \cdot 0^{2,10}\right]$ undecan-3-one (15)

A solution of compound $14(0.60 \mathrm{~g}, 2.3 \mathrm{mmol})$ in THF $(1.6 \mathrm{~mL})$ was added to a mixture of $60 \%$ $\mathrm{NaH}(0.11 \mathrm{~g}, 2.8 \mathrm{mmol})$ cooled in water-ice bath. The mixture was then stirred for 1 hour at room temperature and 6 hours under reflux before extraction with dichloromethane ( $3 \times 2 \mathrm{~mL})$. The organic layer was dried over $\mathrm{MgSO}_{4}$, filtered and the solvent was removed on a rotavapor. The product was purified by silica gel column chromatography using hexane-ethyl acetate (2:1) as eluent: 76\% yield. ${ }^{1} \mathrm{H}-\mathrm{NMR}\left(\mathrm{CDCl}_{3}\right) \delta(\mathrm{ppm}): 1.69$ (ddd, $\left.J=5.0 / 1.5 / 0.7 \mathrm{~Hz}, 1 \mathrm{H}\right), 1.73(\mathrm{~d}, J=11.3 \mathrm{~Hz}, 1 \mathrm{H}), 1.79(\mathrm{~d}, J=$ $11.3 \mathrm{~Hz}, 1 \mathrm{H}), 2.03(\mathrm{~m}, 1 \mathrm{H}), 2.30-2.44(\mathrm{~m}, 5 \mathrm{H}), 2.51$ (t, $J=2.8 \mathrm{~Hz}, 1 \mathrm{H}), 4.35(\mathrm{~m}, 1 \mathrm{H}), 4.55$ (dd, $J=$ 
5.0/2.8 Hz, 1H); ${ }^{13} \mathrm{C}-\mathrm{NMR}\left(\mathrm{CDCl}_{3}\right) \delta$ (ppm): 21.8, $(\mathrm{CH}), 30.3\left(\mathrm{CH}_{2}\right), 30.4\left(\mathrm{CH}_{2}\right), 33.1(\mathrm{C}), 35.3(\mathrm{CH})$, $38.3\left(\mathrm{CH}_{2}\right), 41.8(\mathrm{CH}), 46.3(\mathrm{CH}), 74.1(\mathrm{CH}), 82.2(\mathrm{CH}), 209.4(\mathrm{C}=\mathrm{O})$; MS m/z: $176\left[\mathrm{M}^{+}\right]$.

\section{Biological Evaluation}

\section{Assay for cytotoxic activity}

The cytotoxicity of the compounds was tested against HL-60 (human leukemia), HCT-8 (human colon), SF-295 (human central nervous system) and MDA-MB 435 (human breast cancer) cell lines obtained from the National Cancer Institute, Bethesda, MD, USA. Cells were grown in RPMI-1640 medium supplemented with $10 \%$ fetal bovine serum, $2 \mathrm{mM}$ glutamine, $100 \mu \mathrm{g} / \mathrm{mL}$ streptomycin and $100 \mu \mathrm{g} / \mathrm{mL}$ penicillin and incubated at $37^{\circ} \mathrm{C}$ with a $5 \% \mathrm{CO}_{2}$ atmosphere. Cells were plated in 96-well plates $\left(10^{5}\right.$ cells/well for adherent cells or $0.5 \times 10^{5}$ cells/well for suspended cells in $100 \mu \mathrm{L}$ of medium). After $24 \mathrm{~h}$, the compounds (0.39 to $25.0 \mu \mathrm{g} / \mathrm{mL}$ ) dissolved in DMSO 1\% were added to each well and incubated for $72 \mathrm{~h}$. Control group received the same amount of DMSO. Doxorubicin (Doxolem $^{\circledR}$, Zodiac Produtos Farmacêuticos S/A, Brazil) was used as positive control. Tumor cell growth was quantified by the ability of living cells to reduce the yellow dye 3-(4,5-dimethyl-2thiazolyl)-2,5-diphenyl-2H-tetrazolium bromide (MTT) to a purple formazan product [17]. At the end of the incubation, the plates were centrifuged and the medium was replaced by fresh medium $(200 \mu \mathrm{L})$ containing $0.5 \mathrm{mg} / \mathrm{mL}$ MTT. Three h later, the MTT formazan product was dissolved in DMSO (150 $\mu \mathrm{L}$ ), and absorbance was measured using a multiplate reader (Spectra Count, Packard, Ontario, Canada). The drug effect was quantified as the percentage of the absorbance of reduced dye at $550 \mathrm{~nm}$ in relation to control wells.

\section{Swiss mouse (Mus musculus) erythrocyte hemolysis assay}

The test was performed in 96-well plates following the method described by Costa-Lotufo et al. [23]. Each well received $100 \mu \mathrm{L}$ of $0.85 \% \mathrm{NaCl}$ solution containing $10 \mathrm{mM} \mathrm{CaCl}_{2}$. The first well was the negative control that contained only the vehicle (DMSO 10\%), and, in the second well, test substance $(100 \mu \mathrm{L})$ half was added. The compounds were tested at concentrations ranging from 3.9 to $200 \mu \mathrm{g} / \mathrm{mL}$. The serial dilution continued until the 11 th well. The last well received $0.1 \%$ Triton X-100 in $0.85 \%$ saline $(20 \mu \mathrm{L}$ ) to produce $100 \%$ hemolysis (positive control). Then, each well received a $2 \%$ suspension of mouse erythrocytes in $0.85 \%$ saline containing $10 \mathrm{mM} \mathrm{CaCl}_{2}(100 \mu \mathrm{L})$. After incubation at room temperature for $30 \mathrm{~min}$ and centrifugation, the supernatant was removed and the hemoglobin liberated was measured spectroscopically as absorbance at $540 \mathrm{nM}$.

\section{Statistical Analysis}

The $\mathrm{IC}_{50}$ values and their 95\% confidence intervals (CI 95\%) were obtained by nonlinear regression using the GRAPHPAD program (Intuitive Software for Science, San Diego, CA, U.S.A.). For the hemolytic assay, the differences were analyzed by ANOVA followed by Student Newman Keuls test compared to negative control at a significance level of $5 \%$. 


\section{Acknowledgements}

We are thankful to the Fundação de Apoio ao Desenvolvimento do Ensino, Ciência e Tecnologia do Estado de Mato Grosso do Sul (FUNDECT) and the Financiadora de Estudos e Projetos (FINEP) for financial support in the form of grants and fellowship awards. We also thank to Kardol Indústria Química Ltda., for providing solvents and reagents and Professor Dr. Cláudio F. Tormena (Unicamp) for access to the GC/Mass Spectrometer.

\section{References and Notes}

1. Diels, O.; Alder, K. Synthesen in der hydroaromatischen reihe. Liebigs Ann. Chem. 1928, 460, 98122.

2. Oliveira, K.T. Estudos sintéticos e teóricos sobre anulenos e baquenolidas. Ph.D. Thesis, University of São Paulo. 2006. (for online access see: http://www.teses.usp.br/teses/disponiveis/59/59138/tde-18082006-181618/ )

3. Marchand, P.; Xing, D.; Wang, Y.; Bott, S.G. Improved synthesis of racemic and optically active 4-hydroxycyclohex-2-en-1-one. Tetrahedron Asymmetr. 1995, 6, 2709-2711.

4. Cookson, R.C.; Grundwell, E.; Hudec, J. Synthesis of cage-like molecules by irradiation of DielsAlder adducts. Chem. Ind. (London) 1958, 1003-1004.

5. Govender, T.; Hariprakasha, H.K.; Kruger, H.G.; Raasch. T. Synthesis of Trishomocubane Amino Acid Derivatives. S. Afr. J. Chem. 2005, 58, 37-40.

6. Geldenhuys, W.J.; Malan, S. F.; Bloomquist, J.R.; Marchand, A.P.; Van der Schyf, C.J. Pharmacology and structure - activity relationships of bioactive polycyclic cage compounds: a focus on pentacycloundecane derivatives. Med. Res. Rev. 2005, 25, 22-48.

7. Kitagawa, K.; Mizobuchi, N.; Hama, T.; Hibi, T.; Konishi, R.; Futaki, S. Synthesis and antinociceptive activity of [D-Ala2]Leu-enkephalin derivatives conjugated with the adamantane moiety.. Chem. Pharm. Bull. 1997, 45, 1782-1787.

8. Marchand, A.P.; Allen, R.W. Improved synthesis of pentacyclo[5.4.0.0 $\left.0^{2,6} \cdot 0^{3,10} \cdot 0^{5,9}\right]$ undecane. $J$. Org. Chem. 1974, 39, 1596-1596.

9. Wassermann, A. The mechanism of additions to double bonds. Part I. Thermochemistry and kinetics of a diene synthesis. J. Chem. Soc. 1935, 828-838.

10. Oda, M.; Kawase, T.; Okada, T.; Enomoto, T. Org. Synth. Coll. Vol. IX, 1998; p. 186.

11. Stroermer, M.J.; Butler, D.N.; Warrener, R.N.; Weerasuria, K.D.V.; Fairlie, D.P. Cycloadditions of isobenzofuran to a constrained template bearing neighboring dienophiles. Chem. Eur. J. 2003, 9, 2068-2071.

12. Marchand, A.P.; Reddy, G.M. Mild and highly selective ultrasound-promoted zinc/acetic acid reduction of C:C bonds in $\alpha, \beta$-unsaturated $\gamma$-dicarbonyl compounds. Synthesis 1991, 198-200.

13. Constantino, M. G.; Beatriz, A.; Silva, G.V.J.da.; Zukerman-Schpector, J. Synthetic studies on the diels-alder adduct from 3,4-dimethoxyfuran and benzoquinone. Synth. Commun. 2001, 31, 33293336.

14. Takano, S.; Inomata, K.; Ogasawara, K. A new route to (+)-2,3-(isopropylidenedioxy)-4cyclopentenone via the optically active dicyclopentadiene intermediate. Chem. Lett. 1989, 359362. 
15. Konno, H.; Ogasawara, K. Enantioselective construction and utilization of 2-(cyclohex-2enyl)phenols. Synlett 1998, 1004-1006.

16. Skehan, P.; Storeng, R.; Scudiero, D.A.; Monks, A.; McMahon, J.; Vistica, D.; Warren, J.T.; Bodesch, H.; Kenney, S.; Boyd, M.R. New colorimetric cytotoxicity assay for anticancer-drug screening. J. Natl. Cancer Inst. 1990, 82, 1107-1112.

17. Mosman, T. Rapid colorimetric assay for cellular growth and survival: Application to proliferation and cytotoxicity assays. J. Immunol. Meth. 1983, 65, 55-63.

18. Alley, M.C.; Scudiero, D.A.; Monks, A.; Hursey, M.L.; Czerwinski, M.J.; Fine, D.L.; Abbott, B.J.; Mayo, J.G.; Shoemaker, R.H.; Boyd, M.R. Feasibility of drug screening with panels of human tumor cell lines using a microculture tetrazolium assay. Cancer Res. 1988, 48, 589-601.

19. Berridge, M.V.; Tan, A.S.; McCoy, K.D.; Wang, R. The biochemical and cellular basis of cell proliferation assays that use tetrazolium salts. Biochemica 1996, 4, 15-20.

20. Aki, H.; Yamamoto, M. Drug binding to human erythrocytes in the process of ionic drug-induced hemolysis : flow microcalorimetric approaches. Biochem. Pharmacol. 1991, 41, 133-138.

21. Malheiros, S.V.P.; Meirelles, N.C.; de Paula, E. Pathways involved in trifluoperazine-, dibucaineand praziquantel-induced hemolysis. Biophys. Chem. 2000, 83, 89-100.

22. Furniss, B.S.; Hannaford, A.J.; Smith, P.W.G.; Tachell, A.R. Vogel's Textbook of Practical Organic Chemistry, $5^{\text {th }}$ ed; Longman Scientific \& Technical: New York, 1989; pp. 1025-1026.

23. Costa-Lotufo, L.V.; Cunha, G.M.A.; Fontenele, J.B.; Junior, H.V.N.F.; Sousa, C.M.; Silveira, E.R.; Nogueira, N.A.P.; Moraes, M.O .; Viana, G.S.B. Cytotoxic activity of chalcones isolated from Lonchocarpus sericeus. Phytother. Res. 2003, 17, 155-159.

Sample Availability: Samples of all compounds are available from authors.

(C) 2007 by MDPI (http://www.mdpi.org). Reproduction is permitted for noncommercial purposes. 